\title{
Selective adsorption of plant cysteine peptidases onto $\mathrm{TiO}_{2}$
}

\author{
C.R.F. Llerena-Suster ${ }^{\mathrm{a}}$, M.L. Foresti ${ }^{\mathrm{b}, *}$, L.E. Briand ${ }^{\mathrm{b}}$, S.R. Morcelle ${ }^{\mathrm{a}}$ \\ a Laboratorio de Investigación de Proteínas Vegetales (LIPROVE), Depto. de Cs. Biológicas, Fac. Cs. Exactas, Universidad Nacional de La Plata, Calle 47 y 115, La Plata, Argentina \\ b Centro de Investigación y Desarrollo en Ciencias Aplicadas Dr. Jorge J. Ronco (CINDECA), Universidad Nacional del La Plata - CONICET - CCT La Plata, \\ Calle $47 n^{\circ}$ 257, (B1900AJK) La Plata, Argentina
}

\section{A R T I C L E I N F O}

\section{Article history:}

Received 24 July 2008

Received in revised form 12 February 2009

Accepted 17 March 2009

Available online 27 March 2009

\section{Keywords:}

Plant cysteine peptidases

Selective adsorption

Titanium dioxide

Amidasic activity

\begin{abstract}
A B S T R A C T
A crude extract rich in plant cysteine peptidases was obtained from the latex of the fruits of Araujia hortorum, a South American climbing plant. The highly concentrated extract was immobilized onto titanium dioxide to produce biocatalysts through a simple adsorption procedure. Absorbance measurement at $280 \mathrm{~nm}$ and Bradford's method for protein quantification revealed that the protein content of the crude extract was selectively adsorbed onto the titanium dioxide surface at a very high rate. In $5 \mathrm{~min}$ of contact with the support all protein present in the crude extract was selectively withdrawn from the solution, leading to an immobilized biocatalyst with a high protein concentration. Caseinolytic assays indicated that, except for the catalyst obtained with the highest crude amount contacted with the support, all the proteolytic activity present in the crude extract was adsorbed onto $\mathrm{TiO}_{2}$. The amidasic activity of the immobilized catalysts $\left(\mathrm{Ah} / \mathrm{TiO}_{2}\right)$ was tested in the hydrolysis of a synthetic chromogenic substrate (PFLNA) showing partial deactivation with respect to the native enzyme. In amidasic activity assays the ionic strength of the buffer medium showed to be a key feature to consider in order to avoid protease desorption from the support, indicating the importance of electrostatic interactions between the enzymes and $\mathrm{TiO}_{2}$. Reuse of the produced biocatalysts with PFLNA as substrate revealed that after five successive uses $\mathrm{Ah} / \mathrm{TiO}_{2}$ retained more than $20 \%$ of its initial activity.
\end{abstract}

(C) 2009 Elsevier B.V. All rights reserved.

\section{Introduction}

In the last years enzymes have shown to be powerful catalysts for a number of reactions. In comparison with chemical catalysts enzymes show higher selectivities, they work under milder conditions, and they are environmentally friendlier. Proteases are a family of enzymes that play a prominent role in plant physiology, being the catalysts of processes such as the storage of proteins during seed germination, activation of proenzymes, degradation of defective proteins, etc. [1]. Moreover, proteolytic enzymes are widely used in medicine and industry due to their good solubility, stability and odor. Proteases also play an important role in biotechnology, since proteolysis changes chemical, physical, biological and immunological properties of proteins. This wide range of applications insures proteases the first place in the world market of enzymes. In particular, in the last decades proteolytic enzymes of plant origin have received special attention due to their property of being active in a wide range of temperature and $\mathrm{pH}$. The plant proteinases most widely used in industry are papain and bromelain, both included in the papain-like family [2]. Although the market of commercial proteases includes a high number of those enzymes with high pro-

\footnotetext{
* Corresponding author. Tel.: +54 291486 1700; fax: +54 2914861600.

E-mail address: lforesti@plapiqui.edu.ar (M.L. Foresti).
}

teolytic activity and available at a low cost, there is a need for discovering new plant resources of more active and more specific proteases.

Immobilization of enzymes is a widely used procedure which enables their use in continuous processes, easy separation of product from enzyme, and biocatalyst reuse. Besides, immobilization of enzymes is known to enhance the stability of the immobilized derivative allowing operation at higher temperatures and in some cases in a wider range of $\mathrm{pH}$. For reactions performed in organic media, immobilization may protect the enzyme from solvent denaturation and it may also prevent biocatalyst agglomeration, enhancing the effective area available for catalysis. Among the immobilization methods, adsorption appears as the simplest technique, which implies ionic interactions and other weak bonds such as hydrogen bonding and van der Waals interactions. Adsorption is a mild immobilization method which usually does not affect enzyme activity [3], promoting interactions very similar to those established in biologic membranes. However, under certain conditions adsorption may be reversible, mainly when $\mathrm{pH}$, ionic strength or temperature changes take place. Besides, substrate presence may also lead to enzyme desorption.

The selection of a suitable support for enzyme immobilization must be preceded by characterization studies that yield fundamental information which could then be used as guidelines for other 
enzyme/support systems. In this contribution cysteine proteases obtained from the latex of Araujia hortorum fruits (a climbing plant that grows in Brazil, Paraguay, Uruguay and Argentina) are immobilized onto titanium dioxide by simple adsorption. The search for alternative supports (different from commercial resins and ceramic materials usually used for enzyme immobilization), motivated the assay of inorganic oxides as matrices for enzyme immobilization, and in particular for proteases. It has been reported that oxide supports in the presence of water impart a specific $\mathrm{pH}$ at the surface, which is measured from electrophoretic measurements as the surface $\mathrm{pH}$ at the point of zero charge (pzc) [4]. Since water is the immobilization medium used in this contribution, the inorganic oxides evaluated as potential matrices for proteases adsorption ( $\mathrm{MgO}, \gamma-\mathrm{Al}_{2} \mathrm{O}_{3}, \mathrm{ZrO}_{2}, \mathrm{TiO}_{2}, \mathrm{Nb}_{2} \mathrm{O}_{5}, \mathrm{SiO}_{2}$ ) were analyzed in terms of their surface pzc [4]. Searching for a "neutral" surface that would not deactivate enzymes due to a high acidic or basic nature, $\mathrm{TiO}_{2}$, with a $\mathrm{pH}$ at pzc of 6.0-6.4, was the oxide chosen.

$\mathrm{TiO}_{2}$ (titania) is the principal white pigment in the world, finding use in paint, color pigment, color-printing ink, plastics, enamel, artificial fibers, paper, and rubber [5]. It is non-toxic to the environment and humans, and since 1968 it has been certified as food additive by US [6]. Currently, titanium dioxide is used in a wide range of industries such as in the manufacture of white chocolate, cosmetics, tooth paste, sunscreen and cheese. The fact that titania has no chemical activity in organisms and is not poisonous, makes it attractive not only for food additives but also for food dying, food packaging, cosmetics and medicine. In reference to the properties of the support material chosen, titania has good mechanical, electronic, and optical properties. Although immobilization of other kinds of enzymes on $\mathrm{TiO}_{2}$ and $\mathrm{TiO}_{2}$-coated surfaces has been reported (i.e., pesticide degradable enzyme immobilized on polypropene loaded titanium dioxide membrane [7], adsorption of horseradish peroxidase on $\mathrm{TiO}_{2}$ nanotube arrays, and on titania sol-gel thin films [8,9], etc.), at the best of the authors' knowledge this is the first report dealing with the immobilization of proteases onto titanium dioxide of the anatase type.

\section{Experimental}

\subsection{Materials}

High surface and high purity titanium dioxide support, Degussa P-25 $\left(\mathrm{TiO}_{2}\right.$ anatase, $20-50 \mathrm{~nm}$ particles) was kindly supplied by Lehigh University (USA). After calcination at $500^{\circ} \mathrm{C}$ for $5 \mathrm{~h}$, titanium dioxide with a BET area of $45.7 \mathrm{~m}^{2} / \mathrm{g}$ was obtained. Special nylon filters for small particle powder $(0.45 \mu \mathrm{m})$ were purchased from Osmonics. Coomassie Brilliant Blue G250 (Merck), bovine albumin and casein from bovine milk were purchased from Sigma Chemical Co. PFLNA (L-pyroglutamyl-Lphenylalanyl-L-leucine $p$-nitroanilide) was supplied from Bachem, CA. 1,4-Dithio-D,L-threitol (DTT) was from Invitrogen. The rest of the chemicals and solvents used in this work were of analytical grade.

\subsection{Crude extract (CE) preparation}

Fruits of $A$. hortorum Fourn. were obtained from plants grown in Arana, La Plata, state of Buenos Aires, Argentina (Argentinean folk name: tasi, doca). Fresh latex obtained by superficial incisions of the fruits was gathered on $0.1 \mathrm{M}$ citric acid-citrate buffer ( $\mathrm{pH} 4.5$ ) containing $5 \mathrm{mM}$ EDTA (ethylenediamine tetraacetic acid). The latex suspension was centrifuged at $9600 \times g$ for $30 \mathrm{~min}$ in order to discard most gums and insoluble materials. The result- ing supernatant was lyophilized for further immobilization. Protein content of the crude extract was then determined by comparison with a calibration curve of Bradford assay with BSA as the protein standard. In this way, the protein content of the crude extract was estimated as $25 \%$ respect to the mass of lyophilized powder.

Cation exchange chromatography of the crude extract revealed the presence of six protein fractions, three of which showed proteolytic activity [10]. Isolation and characterization of the three endopeptidases obtained, named araujiain $h I$, araujiain $h$ II and araujiain $h$ III were previously described $[10,11]$.

\subsection{Immobilization procedure}

Different amounts of the lyophilized CE (200, 400 and $800 \mathrm{mg})$ with a protein concentration of approximately $25 \%$ and an enzymatic activity in the standard PFLNA assay of $2.3-2.5 \mathrm{UI} / \mathrm{mg}$ of protein were dissolved in $50 \mathrm{ml}$ of distilled water and centrifuged at $9600 \times g$ for $45 \mathrm{~min}$ at $4{ }^{\circ} \mathrm{C}$. Then the solution was contacted with $1.00 \mathrm{~g}$ of titanium dioxide at $4^{\circ} \mathrm{C}$ with $350 \mathrm{rpm}$ magnetic stirring for $24 \mathrm{~h}$. The immobilization conditions were selected based on previous experience on: (a) the immobilization of other enzymes on different supports; (b) previous knowledge of the group on CE preparation and peptidases characterization of A. hortorum (Asclepiadaceae) fruit latex, and (c) non-deactivating conditions for the proteases present in $\mathrm{CE}$, such as the use of low temperatures and moderate stirring [10-14]. $0.1 \mathrm{M}$ boric acid-sodium borate buffer of $\mathrm{pH} 8.5$ was also tested as immobilization medium since the CE had shown highest caseinolytic activity at alkaline range [11]. Moreover, as the biocatalysts were designed to perform their activities not only in aqueous medium but also in organic media, the $\mathrm{pH}$ value was important, since it is well established that enzymes "remember" the $\mathrm{pH}$ of the last aqueous solution in which they were dissolved and, after water removal, their ionization state remain unchanged (i.e., the optimum to display its maximum activity) [15].

The progress of the immobilization was followed through UV-Vis spectrophotometric determinations of the solution of the $\mathrm{CE}$ in contact with the support. The measurement was performed at $280 \mathrm{~nm}$ in an Agilent 8453E system. With this purpose, $0.5 \mathrm{ml}$ of the supernatant solution was withdrawn at definite intervals during immobilization, filtered with nylon filters $(0.45 \mu \mathrm{m})$ and conserved at $-20^{\circ} \mathrm{C}$ for later spectrophotometric determinations. It was demonstrated that the proteolytic activity of the $\mathrm{CE}$ remains unaltered after storing at $-20^{\circ} \mathrm{C}$ for extended periods of time (data not shown).

At the end of the immobilization period, the solution was centrifuged at $9600 \times \mathrm{g}$ for $3 \mathrm{~min}$ at $4{ }^{\circ} \mathrm{C}$. Supernatant was discarded, and the biocatalyst produced $\left(\mathrm{Ah} / \mathrm{TiO}_{2}\right)$ was washed with distilled water and subjected to further centrifugation. The recovered solid was then dried to constant weight in a regular oven used to grow microorganisms at $25-30^{\circ} \mathrm{C}$ and at ambient pressure. Other procedures for drying the solid (i.e., under vaccum, in the presence of activated silica, etc.) were discarded since they led to a lower recovered activity. UV-Vis absorbance spectra for the initial and the remaining CE solutions after $24 \mathrm{~h}$ of contact with $\mathrm{TiO}_{2}$ in the $200-700 \mathrm{~nm}$ range were also recorded. The theoretical spectrum of the CE adsorbed onto titania was calculated as the difference between the above mentioned spectra.

\subsection{Protein determination}

Proteins present in CE were determined by Bradford's method [16] using BSA as standard. Supernatant samples withdrawn during immobilization were also subjected to protein content determina- 
tion, after being conveniently diluted in order to obtain absorbance values in the appropriate range.

\subsection{Caseinolytic activity assay}

Proteolytic assays of CE and of the supernatant immobilization samples were performed using casein as substrate [17]. The reaction mixture was prepared by mixing $0.1 \mathrm{ml}$ of sample (crude extract solution or supernatant immobilization samples) with $1.1 \mathrm{ml}$ of $1 \%$ casein containing $5 \mathrm{mM}$ cysteine, in a $0.1 \mathrm{M}$ Tris- $\mathrm{HCl}$ buffer (pH 8.0). The reaction was carried out at $37^{\circ} \mathrm{C}$ and stopped after $10 \mathrm{~min}$ by addition of $1.8 \mathrm{ml}$ of $5 \%$ TCA (trichloroacetic acid). Tubes were centrifuged at $3900 \times \mathrm{g}$ for $10 \mathrm{~min}$ and the absorbance of the supernatant was measured at $280 \mathrm{~nm}$. Caseinolytic activity was quantified in terms of the caseinolytic unit $\left(U_{\text {cas }}\right)$ defined by Priolo et al. [18] as the amount of protease which produces an increment of one absorbance unit per min in the assay conditions.

\subsection{Amidasic activity of the immobilized biocatalysts}

Hydrolytic activity of the immobilized biocatalysts was determined using a specific synthetic substrate for plant cysteine endopeptidases L-pyroglutamyl-L-phenylalanyl-L-leucine $p$ nitroanilide (PFLNA) [19]. Reaction medium consisted on $0.1 \mathrm{M}$ phosphate buffer ( $\mathrm{pH}$ 6.5) with $0.1 \mathrm{mM}$ EDTA and $3 \mathrm{mM}$ DTT. Addition of different amounts of $\mathrm{KCl}$ to obtain concentrations ranging from 0 to $0.3 \mathrm{M}$ in the reaction medium was assayed in order to determine the best condition for the hydrolytic assay in terms of biocatalyst activity and stability. The biocatalyst chosen for this test of $\mathrm{KCl}$ effect was the one obtained from $200 \mathrm{mg}$ of $\mathrm{CE}$ in distilled water.

For the immobilized catalyst the amidasic activity test implied the preparation of a suspension containing $5 \mathrm{mg} / \mathrm{ml}$ of $\mathrm{Ah} / \mathrm{TiO}_{2}$ in the phosphate buffer. For comparison, an adequate dilution of the CE solution was also tested. The buffer solution $(1.5 \mathrm{ml})$ and $0.18 \mathrm{ml}$ of a PFLNA stock solution ( $1.5 \mathrm{mM}$ ) in DMSO were added to $0.12 \mathrm{ml}$ of the above mentioned biocatalyst suspensions, giving a final concentration of $0.15 \mathrm{mM}$ in the synthetic substrate. Incubation was performed at $37^{\circ} \mathrm{C}$ for $10 \mathrm{~min}$ in an orbital shaker at $200 \mathrm{rpm}$. After that time, reactions were stopped by adding acetic acid $30 \%(\mathrm{v} / \mathrm{v})$ $(0.5 \mathrm{ml})$. Tubes were centrifuged at $3900 \times \mathrm{g}$ for $20 \mathrm{~min}$ and the absorbance of free $p$-nitroaniline in the supernatant was measured at $410 \mathrm{~nm}$. A calibration curve allowed the determination of the enzymatic international units (IU) defined as the amount of enzyme that produces $1 \mu \mathrm{mol}$ of $p$-nitroaniline per min in the assay conditions. The activity of the immobilized biocatalyst was compared with that found in the $\mathrm{CE}$ in order to determine the percentage of retained activity in $\mathrm{Ah} / \mathrm{TiO}_{2}$.

\subsection{Biocatalyst reuse}

Biocatalyst reuse was assayed in the hydrolysis of PFLNA following the procedure described in the previous section. For reuse assays the biocatalyst chosen was the one obtained from $200 \mathrm{mg}$ and $1 \mathrm{~g}$ of $\mathrm{TiO}_{2}$ contacted in distilled water medium. After the first use of $\mathrm{Ah} / \mathrm{TiO}_{2}$ reaction was stopped by cooling in an icewater bath at $0{ }^{\circ} \mathrm{C}$. Immediately after, the solution was centrifuged and acetic acid was added to the supernatant in order to stop the reaction. Meanwhile, the solid was washed with distilled water, centrifuged in the same conditions as described above, resuspended in $0.1 \mathrm{M}$ phosphate buffer ( $\mathrm{pH} 6.5$ ), and the activity of the washed biocatalyst was measured on PFLNA. This procedure was repeated four more times. Reuse results were expressed with respect to the activity determined in the first batch (100\% activity).

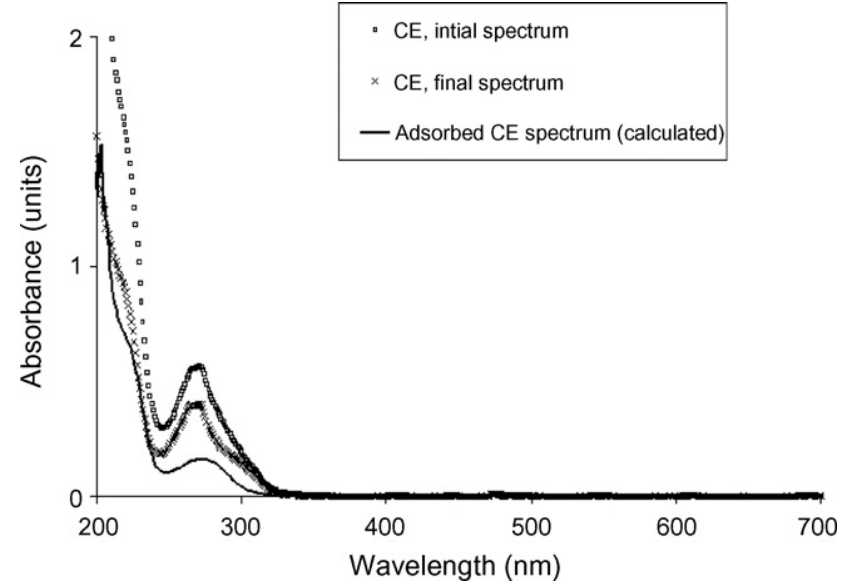

Fig. 1. UV-Vis spectra of the initial CE solution (before adsorption process onto $\mathrm{TiO}_{2}$ ), final CE solution (supernatant remaining after the adsorption) and adsorbed CE onto $\mathrm{TiO}_{2}$. Assay performed for the $400 \mathrm{mg} / 50 \mathrm{ml}$ of distilled water biocatalyst.

\section{Results}

\subsection{Amount of crude extract immobilized onto $\mathrm{TiO}_{2}$}

UV-spectra, comprised in the wavelength range between 200 and $700 \mathrm{~nm}$, were recorded for the initial and final CE solution. The difference between both spectra was calculated to obtain the theoretical spectrum of the adsorbed $C E$ for the biocatalyst obtained from $400 \mathrm{mg}$ of CE contacted with $1 \mathrm{~g}$ of support (Fig. 1). Comparison of both spectra reveals that they are very similar; however, a slight shift of the maximum signal at about $280 \mathrm{~nm}$ - the wavelength that is traditionally attributed to amino acid aromatic residues of proteins [20] - takes place for the adsorbed CE.

As stated in the previous section, during immobilization UV-Vis spectra of supernatant samples were collected in order to determine their absorbance at $280 \mathrm{~nm}$. Fig. 2 shows the time course of CE adsorption obtained when $200 \mathrm{mg}$ of the crude extract were contacted with a gram of support using both, distilled water and pH 8.5 buffer as immobilization medium. For both immobilization media, adsorption of CE extract reaches the same plateau of approximately $41-43 \%$. After adsorption of that fraction of the CE, and irrespectively of the immobilization medium, no further crude is

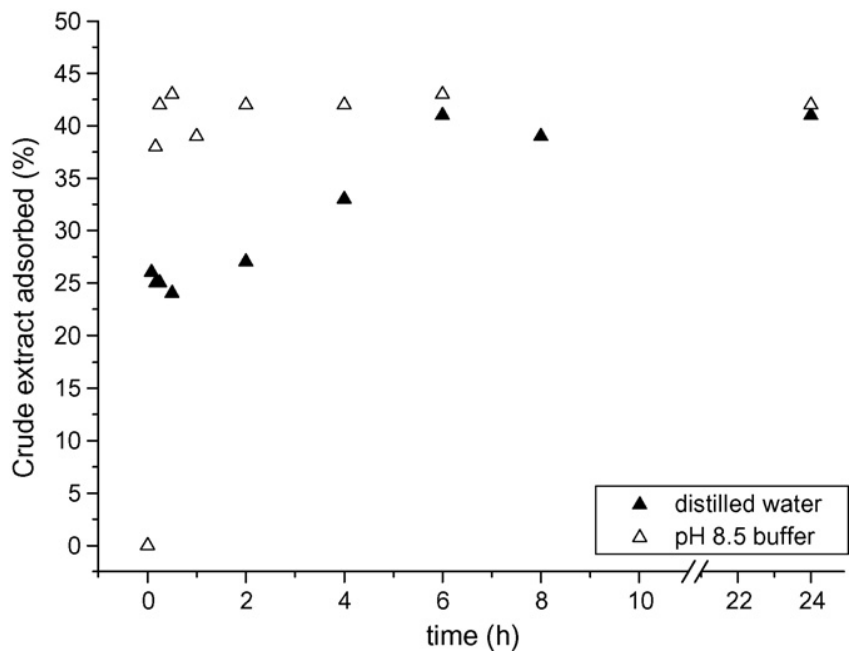

Fig. 2. Time course of $\mathrm{CE}$ adsorption onto $\mathrm{TiO}_{2} .200 \mathrm{mg}$ of $\mathrm{CE}, 1 \mathrm{~g}$ of $\mathrm{TiO}_{2}, 50 \mathrm{ml}$ of distilled water $/ \mathrm{pH} 8.5$ buffer, $4^{\circ} \mathrm{C}, 350 \mathrm{rpm}$. 


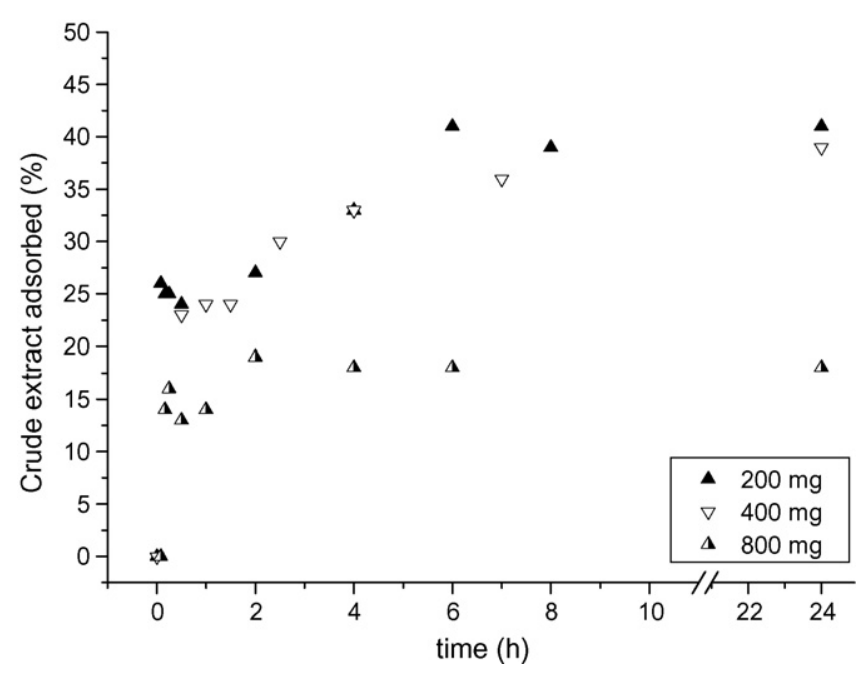

Fig. 3. Time course of $\mathrm{CE}$ adsorption onto $\mathrm{TiO}_{2}$. Effect of the mass of $\mathrm{CE}$ contacted with the support. $1 \mathrm{~g}$ of $\mathrm{TiO}_{2}, 50 \mathrm{ml}$ of distilled water, $4{ }^{\circ} \mathrm{C}, 350 \mathrm{rpm}$.

withdrawn from the supernatant solution. However, as it is shown in Fig. 2, the use of $\mathrm{pH} 8.5$ buffer as immobilization medium leads to a higher immobilization rate with respect to that found in distilled water medium. In the boric acid-sodium buffer case, constant CE concentration in the supernatant solution seems to be reached in only 5-10 min of contact with $\mathrm{TiO}_{2}$ (in the case of distilled water approximately $6 \mathrm{~h}$ were needed).

Fig. 3 illustrates the time course of CE adsorption for increasing amounts of CE contacted with $1 \mathrm{~g}$ of support. In all cases distilled water was used as immobilization medium. As illustrated in Fig. 3, time courses corresponding to 200 and $400 \mathrm{mg}$ of CE show a similar final immobilization yield of approximately $40 \%$. In terms of total mass of extract adsorbed, the amount of CE adsorbed for $400 \mathrm{mg}$ doubles the mass adsorbed when $200 \mathrm{mg}$ of the crude preparation were used. In the case of $800 \mathrm{mg}$ of CE contacted with the support, adsorption data revealed that only $18 \%$ of the initial amount of CE could be withdrawn from solution. As it will be further analyzed in Section 4, it appears that although the use of $800 \mathrm{mg}$ of the enzymatic preparation leads to the highest adsorption rate, agglomeration effects and support saturation limit the total mass of CE adsorbed, therefore reducing the immobilization yield.

\subsection{Amount of protein immobilized onto $\mathrm{TiO}_{2}$}

The protein content of the supernatant samples was determined by Bradford method as described in Section 2 [16]. Comparison of those values with the initial protein content of the CE solutions, allowed the determination of the time course of protein adsorption. Fig. 4 shows the time courses obtained for $200 \mathrm{mg}$ of CE contacted with $1 \mathrm{~g}$ of titanium dioxide in distilled water and in $\mathrm{pH} 8.5$ buffered media. Irrespectively of the $\mathrm{pH}$ of the immobilization medium chosen, results show that when contacted with $\mathrm{TiO}_{2}$ almost all protein present in solution is rapidly adsorbed. As it is illustrated in Fig. 4, in 5 min of contact with the support 97-98\% of the initial protein abandons the enzyme solution, suggesting a strong attraction among proteins present in CE and the titania surface.

Similar results were obtained when the mass of CE contacted with $\mathrm{TiO}_{2}$ was increased to $400 \mathrm{mg}$ (Fig. 5). However, when $800 \mathrm{mg}$ of CE were contacted with the support, protein adsorption was not complete. In this case, a maximum protein adsorption of $69 \%$ was achieved.

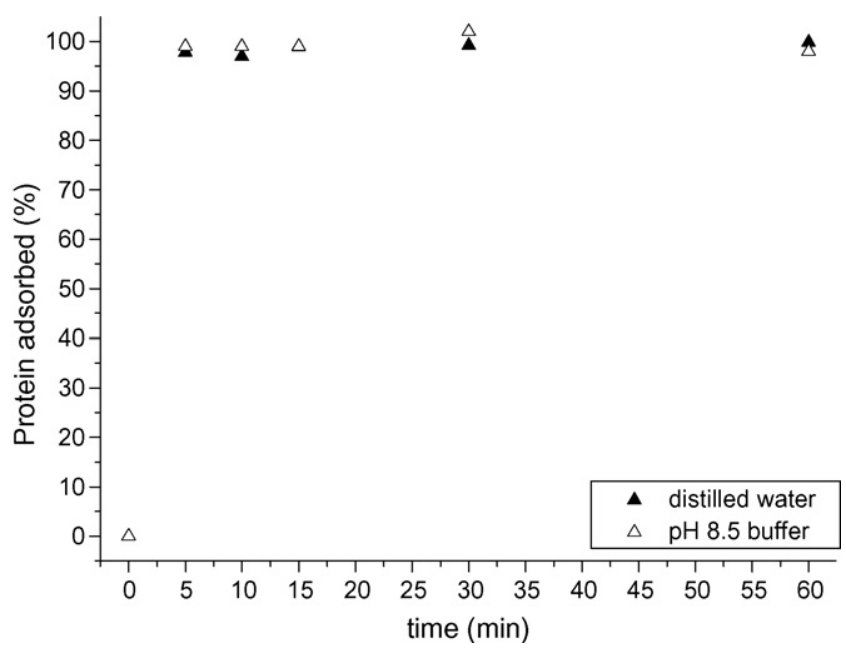

Fig. 4. Time course of protein adsorption onto $\mathrm{TiO}_{2} .200 \mathrm{mg}$ of $\mathrm{CE}, 1 \mathrm{~g}$ of $\mathrm{TiO}_{2}, 50 \mathrm{ml}$ of distilled water $/ \mathrm{pH} 8.5$ buffer, $4^{\circ} \mathrm{C}, 350 \mathrm{rpm}$.

\subsection{Caseinolytic activity}

Proteolytic activity recovered in the supernatant samples was measured on casein as substrate, according to the method described by Arribére et al. [17]. Reduction of caseinolytic activity in supernatant samples may be used as an indirect method for the determination of the protease activity recovered in the immobilized biocatalyst. If all peptidases adsorbed on the support retained the activity shown by their free counterparts, this measurement should give a first approximation of the activity recovered in the different catalysts synthesized. Results for increasing amounts of CE are shown in Fig. 6. Data from the immobilization of $200 \mathrm{mg}$ of CE in buffered medium have also been included.

Fig. 6 illustrates the reduction of proteolytic activity registered in the supernatant solution during the immobilization process. While experiments with 200 and $400 \mathrm{mg}$ evidence a rapid depletion of proteases in the supernatant ( 5 min after immobilization no caseinolytic activity is detected), the assay with $800 \mathrm{mg}$ of CE achieves a plateau after approximately $64 \%$ of the active proteolytic proteins have been withdrawn from solution.

As it was previously pointed out, the results obtained do not imply that the active proteases withdrawn form solution would necessarily remain with the same activity after intimate contact

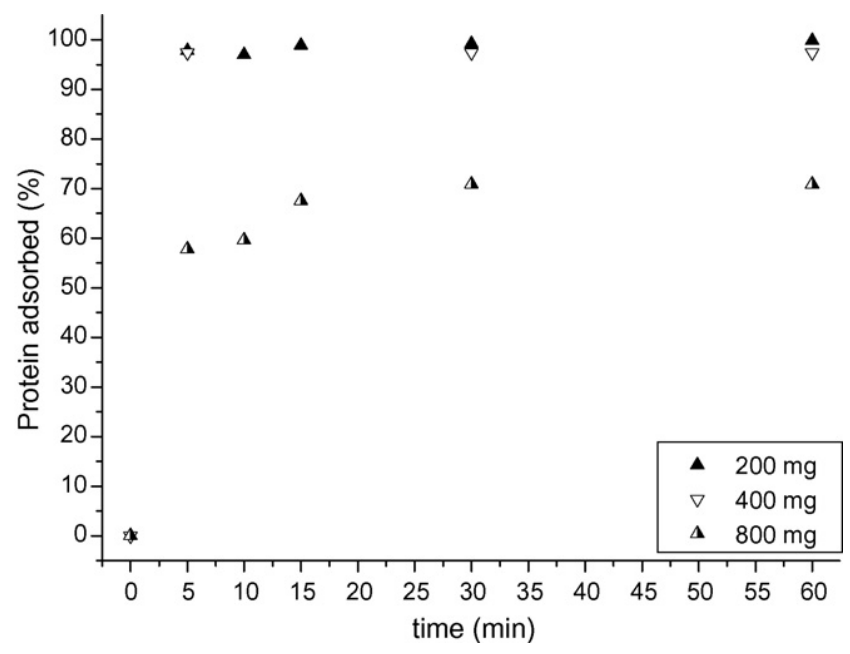

Fig. 5. Time course of protein adsorption onto $\mathrm{TiO}_{2}$. Effect of the mass of $\mathrm{CE}$ contacted with the support. $1 \mathrm{~g}$ of $\mathrm{TiO}_{2}, 50 \mathrm{ml}$ of distilled water, $4{ }^{\circ} \mathrm{C}, 350 \mathrm{rpm}$. 


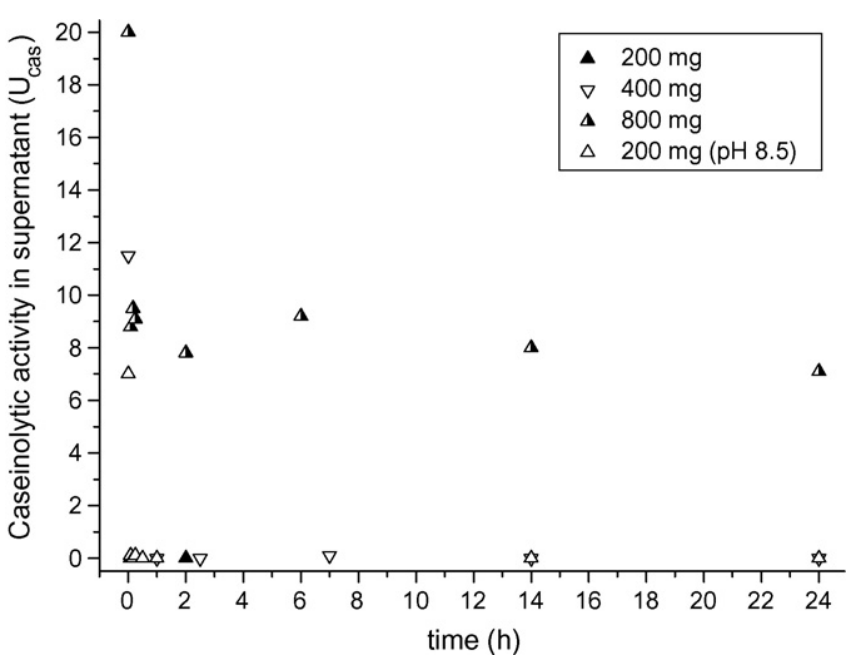

Fig. 6. Caseinolytic activity of supernatant samples during immobilization of $\mathrm{CE}$ onto $\mathrm{TiO}_{2} .1 \mathrm{~g}$ of $\mathrm{TiO}_{2}, 50 \mathrm{ml}$ of distilled water/pH 8.5 buffer, $4^{\circ} \mathrm{C}, 350 \mathrm{rpm}$.

with the support. For those type of conclusions activity assays of the immobilized biocatalysts included in the following section are needed.

\subsection{Amidasic activity}

The hydrolysis of PFLNA substrate was used to check the amount of active enzyme immobilized onto $\mathrm{TiO}_{2}$. In its original version the method proposed by Filippova et al. included the use of $\mathrm{KCl}$ for enhancing the hydrolytic activity of the biocatalyst towards PFLNA [19]. Taking into account that the increase of the ionic strength of reaction medium caused by $\mathrm{KCl}$ might induce enzyme desorption, the beneficial effect of $\mathrm{KCl}$ on the amidasic activity of araujiain towards PFLNA was checked prior to its addition. Results obtained for the free enzyme showed that for the current system there is no significant difference of amidasic activity with or without $\mathrm{KCl}$ addition $(2.3 \mathrm{IU} / \mathrm{mg}$ protein with no $\mathrm{KCl}$ vs. $2.6 \mathrm{IU} / \mathrm{mg}$ protein in $0.3 \mathrm{M} \mathrm{KCl}$ ). The next assay implied proving the hypothesis of enzyme desorption from the immobilized biocatalyst upon use of $\mathrm{KCl}$. For this purpose the biocatalyst chosen was the one obtained from $200 \mathrm{mg}$ of CE in distilled water. Results, which implied the measurement of the amidasic activity of the immobilized biocatalyst and of the supernatant after incubation of $\mathrm{Ah} / \mathrm{TiO}_{2}$ in buffered medium, are shown in Fig. 7. Clearly, the increase in $\mathrm{KCl}$ concentration enhances enzyme liberation. In the presence of $0.3 \mathrm{M} \mathrm{KCl}$, the activity found in the supernatant accounts for $85 \%$ of the total activity. On the other hand, reaction in the absence of $\mathrm{KCl}$ reduces enzyme leaching to $23 \%$. Moreover, in reference to the activity of the desorbed enzyme, for the reaction with $0.3 \mathrm{M} \mathrm{KCl}$ the desorbed enzyme showed a lower activity than the native one, with a total recovered activity of $17-26 \%$ of that of $\mathrm{CE}$ (percentages depend on the biocatalyst assayed). These results suggest that contact of enzyme with the dioxide surface induce some degree of irreversible deactivation. In view of the previous, the standard PFLNA activity determination was modified in order to minimize enzyme desorption induced by the high ionic strength imposed by $\mathrm{KCl}$ presence, and in further assays no $\mathrm{KCl}$ was added to reaction medium. In those conditions, the activity of the immobilized catalysts in PFLNA assay was $0.19 \mathrm{IU} / \mathrm{mg}$ of protein (corresponding to $0.15 \mathrm{IU} / \mathrm{m}^{2}$ per surface area unit of the oxide support for the biocatalyst obtained from $200 \mathrm{mg}$ of CE in distilled water). Results in terms of IU per mg of protein were similar for all biocatalysts obtained, except for the immobilization

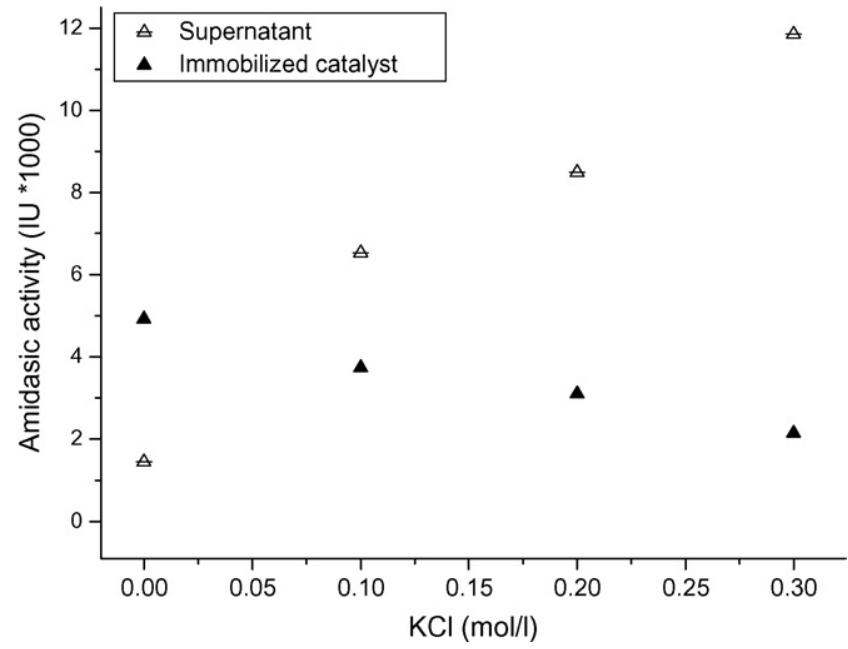

Fig. 7. Enzyme liberation profile for $\mathrm{Ah} / \mathrm{TiO}_{2}$ in $\mathrm{pH} 6.5$ buffer, measured in terms of hydrolytic activity towards PFLNA of the immobilized biocatalyst and of the supernatant solution.

performed in buffered medium which led to an amidasic activity of approximately $40 \%$ of the one obtained in distilled water medium.

In reference to the percentage of activity retained by the synthesized biocatalysts with respect to the $\mathrm{CE}$, serious deactivation of the enzyme was observed. Immobilized proteases showed a total recovered activity of approximately $8 \%$ of the crude extract activity (in the same conditions the CE in the PFLNA assay showed an activity of $2.47 \mathrm{IU} / \mathrm{mg}$ of protein). As it will be further discussed in the following section, conformational rearrangements of the enzyme upon contact with the titania surface may have reduced the enzymatic activity of the immobilized enzyme. Moreover, the drying step showed to be determinant for the activity of the immobilized biocatalyst. In particular, the time devoted to the drying of the immobilized biocatalyst up to constant weight showed to be a key factor, with a final enzymatic activity three times higher when the drying time was reduced from 48 to $24 \mathrm{~h}$. In spite of the previous comment, comparison with literature on the topic evidences that the activity of the immobilized catalyst is still attractive, not only in absolute terms but also in reference to the percentage of retained activity (with respect to the native enzyme activity). In the immobilization of papain and funastrain on polyamide residual enzymatic activity using PFLNA as substrate showed a remaining amidolytic activity of $25 \%$ and $23 \%$, respectively [21]. Moreover, immobilization of a food-grade acid protease on derivatized agarose was reported to retain $16 \%$ of the activity of its original soluble counterpart [22]. Although further attempts to optimize the activity recovered in $\mathrm{Ah} / \mathrm{TiO}_{2}$ are still needed, considering the low cost of the crude extract used as a protease source in this contribution, the recovered activity for $\mathrm{Ah} / \mathrm{TiO}_{2}$ appears attractive. Moreover, the activity and stability of the produced biocatalysts could be tested in organic media (for example in the synthesis of peptides and other related compounds). In this context, it has been reported that the insolubilization of the biocatalyst by immobilization to a solid carrier represents the most relevant biocatalyst engineering strategy for producing robust enzyme catalyst well suited to withstand the harsh conditions prevailing during the reactions of synthesis [23] as well as a tool for enhancing the function of biocatalysts in organic solvents [24]. For this kind of application, the adsorption of the enzyme on a support material before adding it to the solvent by simple methods, is one of the most popular immobilization methods [25]. It has been widely demonstrated that peptidases (papain and 




Fig. 8. Retained activity in subsequent uses of the immobilized catalyst expressed as a percentage of the initial activity (100\%). $5 \mathrm{mg}$ of biocatalyst, $1.62 \mathrm{ml}$ of phosphate buffer, $37^{\circ} \mathrm{C}, 10 \mathrm{~min}$.

trypsin, among others), as well as other enzymes, deposited onto celite, polyamide and other supports by simple adsorption techniques, are the biocatalyst configuration of choice for these kind of applications, even for semipreparative scale of synthesis of valuable products $[21,26-28]$.

\subsection{Biocatalyst reuse}

Reuse of $\mathrm{Ah} / \mathrm{TiO}_{2}$ was assayed in the hydrolysis of PFLNA without addition of $\mathrm{KCl}$. Data included in Fig. 8 show the amidasic activity registered for subsequent uses of $\mathrm{Ah} / \mathrm{TiO}_{2}$. As it is shown in Fig. 8, the activity of the immobilized catalyst is gradually reduced with the number of uses. Although lower than if $\mathrm{KCl}$ was added to reaction medium, leaching of enzyme which is attached to the support by simple adsorption surely accounts for a fraction of the activity lost. Moreover, vigorous stirring necessary for renewed suspension of the biocatalyst after centrifugation may also be responsible for partial enzyme deactivation promoted by the high stresses developed.

\section{Discussion}

\subsection{Selective adsorption of a fraction of the crude extract}

As illustrated in Figs. 2 and 3 of Section 3, contact of 200 and $400 \mathrm{mg}$ of $\mathrm{CE}$ with $1 \mathrm{~g}$ of $\mathrm{TiO}_{2}$, led to a similar immobilization yield of approximately $40 \%$. In the case of using buffered medium instead of distilled water, adsorption of CE led to the same final yield although the process was significantly faster: the mentioned final yield was achieved in only 5-10 min of contact, compared with the $6 \mathrm{~h}$ required by the non-buffered media. A plausible explanation for the previous observation is the reinforcement of electrostatic interactions established between the support and the peptidases due to the development of opposite charges (in enzymes and the support) at $\mathrm{pH}$ 8.5. At the mentioned $\mathrm{pH}, \mathrm{TiO}_{2}$ shows negative surface charge, being $\mathrm{Ti}_{2} \mathrm{O}^{-}$the predominant species [29]. Besides, at $\mathrm{pH} 8.5$ endopeptidases present in the crude extract have a positive charge since araujiain $h I$ and araujiain $h$ III have a pI higher than 9.3 , whereas pI of araujiain $h$ II is $8.9[10,11]$. Although at $\mathrm{pH} 8.5$ endopeptidases are close to their $\mathrm{pI}$ (and thus the positive charges developed should be small) the negative charges developed in titania seem to be enough for an intense and rapid interaction. At lower $\mathrm{pH}$ values (those of distilled water, ca 5.0), the predominant superficial groups of $\mathrm{TiO}_{2}$ are $\mathrm{Ti}_{2} \mathrm{OH}$, which could be the respon- sible for the slower adsorption of proteins onto the surface due to a weaker interaction. Adsorption of different proteins on various synthetic adsorbents in many cases has been attributed to electrostatic interaction [29-34]. Furthermore, adsorption of different amino acids and proteins onto $\mathrm{TiO}_{2}$ has also been described in terms of the following electrostatic interactions: (a) interactions between the slightly negatively charged $\mathrm{TiO}_{2}$ surface and positively charged groups (e.g. $-\mathrm{NH}_{3}{ }^{+}$); (b) moieties of the biomolecule and electrostatic binding between the $\mathrm{TiO}_{2}$ surface and negatively charged groups of the amino acid $\left(-\mathrm{COO}^{-}\right)$; (c) domains in the protein through $\mathrm{Ca}^{2+}$ bridges. Moreover, direct coordination of the carboxylate $\left(-\mathrm{COO}^{-}\right)$group with $\mathrm{Ti}$ cations replacing hydroxy groups at the hydroxylated oxide surface has also been proposed [35].

Irrespectively of the kind of forces involved in the enzymatic extract adsorption onto $\mathrm{TiO}_{2}$, the plateau at $40 \%$ of $\mathrm{CE}$, suggests the presence of a component - or a group of components - in CE that account for approximately $40 \%$, and that are selectively adsorbed onto $\mathrm{TiO}_{2}$. After these components have been withdrawn from the supernatant solution, no further adsorption takes place.

The increase of the amount of CE contacted with titania up to $400 \mathrm{mg}$ also gave a final constant yield of approximately $40 \%$. The fact that duplicating the amount of CE contacted with the support allowed the withdrawal from solution of twice the mass of $\mathrm{CE}$, indicates that the area available in $1 \mathrm{~g}$ of $\mathrm{TiO}_{2}$ does not limit CE adsorption to $40 \%$ in the experiments with $200 \mathrm{mg}$ of $\mathrm{CE}$ added. Moreover, the repeated final yield reinforces the hypothesis that there are some compounds in CE that account for approximately $40 \%$ which are selectively adsorbed onto the surface of the titanium dioxide. Other components of $C E$ that absorb at $280 \mathrm{~nm}$ but are not withdrawn from solution upon contact with the support may be peptides and other compounds containing purine and pyrimidine rings, such as nucleic acids and nucleotides which could interfere with this determination [20].

In the case of the assay of $800 \mathrm{mg}$ of CE, UV-Vis results indicate that the immobilization percentage is approximately $18 \%$, which implies that the amount of CE adsorbed for this assay is similar to the one adsorbed for the assay in which $400 \mathrm{mg}$ of $\mathrm{CE}$ were used ( $144 \mathrm{vs.} 156 \mathrm{mg}$, respectively). The lower immobilization efficiency obtained for the assay with $800 \mathrm{mg}$ of CE may be explained in terms of both, (a) CE agglomeration, and/or (b) support saturation. CE is known to have gums and other compounds such as nucleic acids and peptides. Although the centrifugation step highly reduces the concentration of the gums and other insoluble material present in the latex, some of them may remain in solution, promoting CE aggregation. This effect, which is surely enhanced for increasing masses of $\mathrm{CE}$, could promote the formation of enzyme aggregates leading to a lower effective area available for the contact with $\mathrm{TiO}_{2}$ surface.

On the other hand, the fact that the total amount of CE adsorbed per mass of catalyst and surface area unit of the oxide support for the biocatalyst obtained from adsorption of $800 \mathrm{mg}$ was very similar to the one measured for the assay with $400 \mathrm{mg}$ of $\mathrm{CE}$, also introduces the possibility of the saturation of the support for immobilization achieved with CE amounts close to $400 \mathrm{mg}$ (see Table 2 later on). If the enzyme powder was a purified preparation containing a single protease whose dimensions were known (as it is the case of papain or several lipases such as CALB [36,37]), a simple calculus considering the BET area of $\mathrm{TiO}_{2}$ could give a theoretical value of the amount of enzyme needed for a monolayer adsorption. Then, the mass of enzyme determined from UV-Vis at $280 \mathrm{~nm}$ measurements could be contrasted with the theoretical monolayer value, and it could be determined whether saturation of the support has been achieved. This kind of calcu- 
Table 1


contact with the oxide support.

\begin{tabular}{|c|c|c|c|c|c|c|c|}
\hline \multirow[t]{2}{*}{$\begin{array}{l}\text { Mass of CE contacted } \\
\text { with } \mathrm{TiO}_{2}(\mathrm{mg})\end{array}$} & \multirow[t]{2}{*}{$\begin{array}{l}\text { Protein concentration } \\
(\mathrm{mg} / \mathrm{ml})^{\mathrm{a}}\end{array}$} & \multirow[t]{2}{*}{$\begin{array}{l}\text { Enzymatic activity } \\
(\mathrm{IU} / \mathrm{ml})^{\mathrm{b}}\end{array}$} & \multirow[t]{2}{*}{$\begin{array}{l}\text { Enzymatic activity } \\
\left(U_{\text {cas }} / \mathrm{ml}\right)^{\mathrm{c}}\end{array}$} & \multicolumn{2}{|c|}{$\begin{array}{l}\text { Amount adsorbed in } \\
\underline{5 \mathrm{~min}(\mathrm{mg})}\end{array}$} & \multicolumn{2}{|c|}{$\begin{array}{l}\text { Maximum amount } \\
\text { adsorbed (mg) }(24 \mathrm{~h})\end{array}$} \\
\hline & & & & $\mathrm{CE}^{\mathrm{d}}$ & Protein ${ }^{\mathrm{e}}$ & $C E^{d}$ & Protein $^{e}$ \\
\hline 200 & 0.95 & 2.44 & 6.8 & 50 & 50.5 & 84 & 50.5 \\
\hline 400 & 2.19 & 4.91 & 11.5 & 96 & 89.6 & 156 & 89.6 \\
\hline 800 & 3.65 & 7.69 & 20.0 & 112 & 108 & 144 & 129.2 \\
\hline $200_{b}$ & 0.92 & 2.08 & 7.0 & 76 & 44.1 & 84 & 44.1 \\
\hline
\end{tabular}

Subscript b accounts for buffer medium.

a Protein concentration determined as the average of three Bradfordǐs assays.

b $\mathrm{IU} / \mathrm{ml}$ : amount of enzyme that produces $1 \mu \mathrm{mol}$ of $p$-nitroanilina per min per $\mathrm{ml}$ of sample.

c Ucas/ml: amount of enzyme which produces an increment of one absorbance unit per min.

d The absorbance at $280 \mathrm{~nm}$ of the starting mass of CE was used as a reference to calculate the amount of CE adsorbed.

e Bradford results for the starting mass of proteins (determined from the protein concentration and the volume of solution) was used as reference to calculate the amount of protein adsorbed upon time.

lus, which is only possible for highly purified preparations, is also useful to infer if monolayer or multilayer immobilization is taking place.

\subsection{Selective adsorption of proteins}

Protein quantification assays of the supernatant samples withdrawn during immobilization, allowed the determination of the amount of protein remaining in the solution. In the case of experiments with $200 \mathrm{mg}$ of CE in distilled water and in buffered media, and also for the experiment with $400 \mathrm{mg}$ of $\mathrm{CE}$, those assays revealed complete protein adsorption in only 5 min of contact with $\mathrm{TiO}_{2}$. This is a remarkable result, since it reveals that although only $40 \%$ of CE is withdrawn from solution, all proteins present in the crude are selectively (and almost instantaneously) adsorbed onto $\mathrm{TiO}_{2}$. This idea is reinforced by the shift of the absorbance relative maximum of the calculated spectrum for the adsorbed CE towards the UV region of $280 \mathrm{~nm}$ (Fig. 1).

Moreover, comparison of the time courses of adsorption obtained from absorbance at $280 \mathrm{~nm}$ (total CE, Figs. 2 and 3) and from protein assay (total protein, Figs. 4 and 5) for 200 and $400 \mathrm{mg}$ reveal that, while the protein time courses reach a plateau in the first 5 min of immobilization, the temporal evolution of CE adsorption show a two-step increment. As it is shown in Figs. 2 and 3, in $5 \mathrm{~min}$ of contact CE time courses reach a first value of approximately $24-25 \%$, followed by a slower increment which finally leads to the final $40 \%$ plateau. Considering that the amount of protein of the enzymatic extract accounts for approximately 25\% (Section 2.2 ), and that protein quantification assays reveal that proteins are adsorbed in $5 \mathrm{~min}$ of contact with $\mathrm{TiO}_{2}$, it appears clear that the first components which account for the initial adsorption evidenced in the $280 \mathrm{~nm}$ time courses are proteins. The remaining adsorbed components (approximately a 15\% of the total CE), which also contribute to absorbance at $280 \mathrm{~nm}$, are not detected by the Bradford's quantification method and caseinolytic activity assays. Furthermore, those components show a lower attraction for the oxide support, which is evidenced by their adsorption at a lower rate.
In reference to the assay with $800 \mathrm{mg}$ of crude contacted with $1 \mathrm{~g}$ of titania, results of protein quantification assay by Bradford's method reveal a first step of $58 \%$ of protein withdrawn in the first 5 min of contact, followed by a second slower adsorption step which leads to a final value of $70 \%$ of the protein measured in the initial solution (Fig. 5). Besides, considering the time courses of total CE adsorption, Fig. 3 shows a first step which achieves an adsorption of 14-15\% of $\mathrm{CE}$ in 5 min of contact with $\mathrm{TiO}_{2}$. After that time adsorption continues at a lower rate to finally reach a plateau for $18 \%$ of CE withdrawn from solution. Taking into account that CE contains approximately $25 \%$ of protein, these results imply that also for the assay with $800 \mathrm{mg}$ of $\mathrm{CE}$, in the first $5 \mathrm{~min}$ of contact proteins are selectively adsorbed. In fact, for this catalyst, comparison of final values of the adsorption time courses (Table 1, third line) reveal that practically only proteins are adsorbed, accounting for the total $18 \%$ of the CE withdrawn from solution and determined by absorbance at $280 \mathrm{~nm}$ measurements. The high concentration of proteins in the catalyst obtained from $800 \mathrm{mg}$ of CE is evidenced in Table 2, in which immobilization data is reported in terms of both mass of CE and protein per total mass of catalyst and surface area of the oxide support.

Finally, in reference to the assay performed in buffered medium (last line of Table 1), a different behavior is observed: in this case a unique rapid adsorption step is shown by absorbance at $280 \mathrm{~nm}$ measurements (see also Fig. 2). As it has been introduced in the previous section the electrostatic interactions established between negatively charged titania and the slightly charged proteins could be the driving force for a higher adsorption rate in buffered medium. In that case ionic forces established between charged species promote a one step complete adsorption of the final yield of $39-42 \%$.

\subsection{Activity recovered in the immobilized biocatalysts}

Activity determinations were performed on casein and PFLNA as substrates. While the PFLNA assay was performed on supernatant solution as well as on the immobilized catalyst, casein determinations were only used for supernatant samples. The large size of

Table 2

Mass of CE and mass of protein adsorbed per total mass and per surface area unit of support in synthesized biocatalysts.

\begin{tabular}{|c|c|c|c|c|}
\hline $\begin{array}{l}\text { Mass of CE contacted } \\
\text { with } \mathrm{TiO}_{2}(\mathrm{mg})\end{array}$ & $\begin{array}{l}\text { Mass of } \mathrm{CE} / \text { mass of } \\
\text { catalyst }(\%)\end{array}$ & $\begin{array}{l}\text { Mass of } \mathrm{CE} / \text { surface area } \\
\text { of support }\left(\mathrm{mg} / \mathrm{m}^{2}\right)\end{array}$ & $\begin{array}{l}\text { Mass of protein/mass } \\
\text { of catalyst (\%) }\end{array}$ & $\begin{array}{l}\text { Mass of protein/surface } \\
\text { area of support } \\
\left(\mathrm{mg} / \mathrm{m}^{2}\right)\end{array}$ \\
\hline 200 & 7.7 & 1.8 & 4.8 & 1.1 \\
\hline 400 & 13.5 & 3.4 & 8.2 & 2.0 \\
\hline 800 & 12.6 & 3.2 & 11.4 & 2.8 \\
\hline $200_{b}$ & 7.7 & 1.8 & 4.2 & 1.0 \\
\hline
\end{tabular}

Subscript b accounts for buffer medium. 
casein molecule is suspected to lead to diffusion-controlled rates when immobilized catalysts are assayed [38].

As it is shown in Fig. 6, caseinolytic activity results reveal that for the biocatalysts obtained from 200 and $400 \mathrm{mg}$ adsorption is rapid and complete, while when using $800 \mathrm{mg}$ of CE only a fraction of active enzyme is withdrawn by the support. However, and as it was pointed out in Section 3, withdrawal of active enzyme from solution does not imply that all peptidases will remain in its native active conformation once adsorbed on the titania surface. In fact protein conformational change, which results in entropic gain, is thought to be one of the important driving force of protein adsorption [34]. The structural rearrangement will usually produce more disordered states, and the corresponding change in entropy will provide an extra driving force for adsorption [40]. It has been reported that this extra driving force may overcome apparently unfavorable protein-surface interactions which may adsorb on under unfavorable electrostatic interactions [40].

In the case of the immobilized biocatalysts, although an attractive amidolytic activity was determined, PFLNA assays demonstrated that, in comparison with the native proteases, the biocatalysts produced evidence a high percentage of enzyme deactivation after contact with the support. Changes on the native conformation of the enzymes upon contact with the support surface may have distorted its secondary structure, reducing its activity. In the adsorption of $\alpha$-chymotrypsin onto silica OX-50 and Teflon supports, the proteolytic enzyme showed an important loss of activity upon adsorption [34]. Spectrophotometric as well as calorimetric experiments indicated severe structural rearrangements resulting from adsorption. Moreover, authors found that the loss of activity was in general agreement with structural features, which in the case of silica was evidenced by an important loss of $\alpha$-helix structure determined by circular dichroism [34]. In the case of the current adsorption of CE onto titania, immobilization in a medium of $\mathrm{pH} 8.5$ led to the highest reduction of activity. Evidently, stronger electrostatic interactions generated in that medium might have enhanced enzyme structure distortion, since higher protein-surface interactions are known to cause a larger degree of conformational change on adsorption. In this context, Kondo and Mihara [39] concluded that electrostatic interactions were one of the important factors which determine the extent of conformational changes of adsorbed proteins.

Another reason for activity loss of the immobilized catalysts was the drying step performed after recovery of the supported catalyst from the immobilization solution. Experiments devoted to the optimization of the recovery process are currently been performed in order to increase the percentage of activity retained.

Finally, the results obtained from the assays in the presence of $\mathrm{KCl}$ evidenced high enzyme leaching, reinforcing the hypothesis of an adsorption mechanism based on electrostatic interactions. Even though desorbed peptidases showed higher activity than the immobilized catalysts, measured activity was lower than that of their native counterparts, suggesting that the deactivation imposed by the adsorption step could not be totally reverted upon desorption in a medium of high ionic strength. In the work of Zoungrana et al. [34] authors also found that during incubation of $\alpha$-chymotrypsin onto a silica support, exchange of protein molecules between the hydrophilic surface and the solution leads to a strong reduction of helical structure and the original structure is not restored upon release from the surface.

\section{Conclusion}

A crude extract rich in plant cysteine peptidases was successfully immobilized onto titanium dioxide following a simple adsorption procedure. UV-Vis determinations revealed that the adsorption was highly selective towards proteins, which were selectively withdrawn from the immobilization solution in 5 min of contact with $\mathrm{TiO}_{2}$.

Activity determinations performed on immobilization solution samples confirmed that adsorption of peptidases is rapid and complete. However, the immobilized enzymes do not retain the activity of their crude counterparts, showing a recovered amidasic activity of $8 \%$. Severe structural rearrangements resulting from adsorption must have taken place, leading to an immobilized enzyme with lower activity than their soluble counterpart. Drying of the immobilized biocatalyst after recovery from the enzyme solution also must have played a role in the reduction of enzyme activity observed.

In spite of the previous, the low cost of the crude extract used as protease source, and the high concentration of proteins of the synthesized biocatalyst still reveal $\mathrm{Ah} / \mathrm{TiO}_{2}$ as an attractive immobilized proteolytic catalyst with a retained enzymatic activity close to the ones found in literature for other proteases.

\section{Acknowledgements}

Authors acknowledge Consejo Nacional de Investigaciones Científicas y Técnicas (CONICET), Universidad Nacional de La Plata (UNLP, Project X-445) and Agencia de Promoción Científica y Técnica (ANPCyT, PICT Redes 729/06 and PICT $\mathrm{N}^{\circ} 38088$ ) for financial support. CRFLS was awarded with an ANPCyT fellowship (PICT $\mathrm{N}^{\circ}$ 38088). MLF, LEB and SRM are members of CONICET Researcher Career. Luis E. Moracci and María Elisa Fait technical assistance is also acknowledged.

\section{References}

[1] G.N. Rudenskaya, A.M. Bogacheva, A. Preusser, A.V. Kuznetsova, Y.E. Dunaevsky, B.N. Golovkin, V.M. Stepanov, FEBS Lett. 437 (1998) 237.

[2] D. Vallés, S. Furtado, A.M.B. Cantera, Enzyme Microb. Technol. 40 (2007) 409

[3] F. Godia Casablanca, J. López-Santín, in: Godia-Casablanca, J. López-Santín (Eds.), Ingeniería bioquímica, Editorial Síntesis, Madrid, 1998.

[4] G. Deo, I.E. Wachs, J. Haber, Crit. Rev. Surf. Chem. 4 (3-4) (1994) 141.

[5] Q. Yuan, N. Luo, Adv. Chem. Ind. 5 (1997) 5.

[6] Summary of color additives listed for use in the United States in food, drugs, cosmetics, and medical devices, U.S. Department of Health \& Human Services U.S. Food \& Drug Administration Center for Food Safety \& Applied Nutrition Food Ingredients and Packaging, CITE: 21CFR73.575.

[7] Q. Zhang, B. Tang, L. Fang, C. Zhang, Trans. ASAE 22 (3) (2006) 19.

[8] S. Liu, A. Chen, Langmuir 21 (18) (2005) 8409.

[9] J. Yu, H. Ju, Anal. Chem. 74 (14) (2002) 3579.

[10] W.D. Obregón, M.C. Arribére, S. Morcelle del Valle, C. Liggieri, N.O. Caffini, N.S. Priolo, J. Protein Chem. 20 (2001) 17.

[11] N. Priolo, S. Morcelle del Valle, M.C. Arribére, L.M.I. López, N.O. Caffini, J. Protein Chem. 19 (2000) 39.

[12] M.L. Foresti, M.L. Ferreira, Catal. Today 107-108 (2005) 23-30.

[13] M.L. Foresti, M.L. Ferreira, Enzyme Microb. Technol. 40 (4) (2007) 769-777.

[14] M.L. Foresti, A. Errazu, M.L. Ferreira, Biochem. Eng. J. 25 (1) (2005) 69-77.

[15] P. Adlercreutz, Immobilization of enzymes for use in organic media in "Immobilization of enzymes and cells", in: M. José, Guisan (Eds.), Methods in Biotechnology, 2nd Ed., Humana Press, Totowa, New Jersey, 2007, pp. 251-256.

[16] M.M. Bradford, Anal. Biochem. 72 (1976) 248.

[17] M.C. Arribére, A.A. Cortadi, M.A. Gattuso, M.P. Bettiol, N. Priolo, N.O. Caffini, Phytochem. Anal. 9 (1998) 267.

[18] N. Priolo, L.M.I. López, M.C. Arribére, C.L. Natalucci, N.O. Caffini, Acta Alimentaria 20 (1991) 189.

[19] I.Y. Filippova, E.N. Lysogorskaya, E.S. Oksenoit, G.N. Rudenskaya, V.M. Stepanov, Anal. Biochem. 143 (1984) 293.

[20] M.J. Dumm, in: HarrisF E.L.V., S. Angal (Eds.), Protein purification methods-a practical approach, IRL Press, Oxford, 1989.

[21] S.R. Morcelle, S. Barberis, N. Priolo, N.O. Caffini, P. Clapés, J. Mol. Catal. B: Enzym. 41 (2006) 117.

[22] A.T. Bakalinsky, R. Boulton, Am. J. Enol. Vitic. 36 (1) (1985) 23.

[23] F. Guzmán, S. Barberis, A. Illanes, Electron. J. Biotechnol. 10 (2007) 279

[24] Y.L. Khmelnistky, J.O. Rich, Curr. Opin. Chem. Biol. 3 (1999) 47.

[25] M.N. Gupta, I. Roy, Eur. J. Biochem. 271 (2004) 2575.

[26] P. Clapés, M.C. Morán, M.R. Infante, Biotechnol. Bioeng. 63 (3) (1999) 333.

[27] E. Piera, M.R. Infante, P. Clapés, Biotechnol. Bioeng. 70 (2000) 223.

[28] M.C. Morán, M.R. Infante, P. Clapés, J. Chem. Soc., Perkin Trans. 1 (2001) 2063.

[29] F.Y. Oliva, L.B. Avalle, O.R. Camara, C.P. de Pauli, J. Colloid Interface Sci. 261 (2003) 299.

[30] T. Arai, W. Norde, Colloids Surf. 51 (1990) 17 
[31] H.S. Lui, Y.C. Yang, Colloids Surf. B 5 (1995) 35

[32] H.W. Yang, C. Viera, J. Fischer, M.R. Etzel, Ind. Eng. Chem. Res. 41 (2002) 1597

[33] X. Zhang, R. Bai, Y.W. Tong, Sep. Purif. Technol. 52 (2006) 161.

[34] T. Zoungrana, G. Findenegg, W. Norde, J. Colloid Interface Sci. 190 (1997) 437.

[35] K. Rezwan, L.P. Meier, L.J. Gauckler, Langmuir 21 (2005) 3493.
[36] J. Drenth, J.N. Jansonius, R. Koekoek, H.M. Swen, B.G. Wolthers, Nature 218 (1968) 929.

[37] J. Uppenberg, M.T. Hansen, S. Patkar, T.A. Jones, Structure 2 (1994) 293.

[38] T. Hayashi, Y. Ikada, J. Appl. Pol. Sci. 42 (1991) 85.

[39] A. Kondo, J. Mihara, J. Colloid Interface Sci. 177 (1996) 214

[40] A. Ball, R.A.L. Jones, Langmuir 11 (1996) 3542. 